\title{
PEMBERDAYAAN SEKEHE PATUS NGABEN SARWA GUNA YADNYA DI DUSUN SILAKARANG, GIANYAR
}

\author{
Putu Adi Suprapto, I Kadek Ervan Hadi Wiryanta, dan Ni Made Wirasyanti Dwi Pratiwi \\ Politeknik Negeri Bali \\ E-mail: putuadisuprapto@gmail.com
}

\begin{abstract}
ABSTRAK. Ngaben merupakan suatu proses penyucian atma/roh saat meninggalkan badan kasar, dengan menggunakan sarana api sehingga bisa kembali ke Sang Hyang Pencipta yaitu Brahma. Berdasarkan awig-awig Dusun Silakarang terdapat dan berlaku 2 (dua) sistem upacara ngaben, yakni: ngaben massal (bersama-sama) dan ngaben dadakan, yang memiliki prinsip sama, yakni bertujuan mempercepat pengembalian roh ke sang pencipta. Mitra dalam kegiatan ini adalah Sekehe Patus Ngaben Sarwa Guna Yadnya, yang salah satu bidang usaha yang dimiliki saat ini adalah penyewaan alat-alat upacara, seperti: sanggah, tenda, pemiosan, mesin ebat, kompor, wajan, kursi, talenan, alat masak, kompor mayat, jasa pembakaran mayat. Keberadaan usaha penyewaan tersebut saat ini kurang optimal disebabkan karena kurang dikelola secara profesional dan ketersediaan alat belum lengkap untuk dapat disewakan secara komersil. Berdasarkan permasalahan yang dihadapi tersebut, maka akan direncanakan dan dilaksanakan kegiatan secara bertahap dalam upaya pemberdayaan organisasi/sekehe tersebut. Kegiatan diawali dengan sosialiasasi kepada anggota sekehe, kemudian dilanjutkan dengan melakukan kegiatan penguatan kelembagaan melalui penyusunan aturan/awig dan struktur organisasi. Selanjutnya Tim Pengabdian memberikan bantuan alat-alat yang dapat disewakan seperti Mesin Penggiling Daging, Parut Kelapa kecil dan Parut Kelapa Besar, memberikan Tenda dengan ukuran yang umumnya dicari di pasaran, dan yang terakhir tim memberikan pelatihan manajemen keuangan. Indikator capaian adalah terwujudnya awig dan struktur organisasi, merealisasikan usaha penyewaan alat yang lebih profesional dan bernilai ekonomi yang tinggi, yang mampu meningkatkan pendapatan Sekehe hingga 80\% (delapan puluh persen) per bulan, dan mampu mengetahui omset sekehe per bulannya melalui laporan keuangan sederhana.
\end{abstract}

Kata kunci: Pemberdayaan; Sekehe Patus; Ngaben

ABSTRACT. Ngaben is a process of cleansing atma / spirit when leaving a rough body, using the means of fire so that it can return to Sang Hyang the Creator, Brahma. Based on the awig-awig Silakarang Hamlet there are and apply 2 (two) Ngaben ceremonies, namely: mass ngaben (together) and impromptu ngaben, which have the same principle, which is aimed at accelerating the return of spirits to the creator. Partners in this activity are Sekehe Patus Ngaben Sarwa for Yadnya, which is one of the fields of business currently owned is the rental of ceremonial tools, such as: sanggah, tents, pemiosan, heavy machinery, stoves, frying pans, chairs, cutting boards, cooking utensils, corpse stove, corpse services. The existence of the rental business is currently not optimal due to lack of professional management and the availability of incomplete tools to be leased commercially. Based on the problems faced, the activities will be planned and carried out in stages in an effort to empower the organization. Activities begin with socialization to the same members, then proceed with conducting institutional strengthening activities through the formulation of rules / regulations and organizational structure. Furthermore, the Service Team provided assistance for leasing tools such as Meat Grinding Machines, Small Coconut Grate and Large Coconut Grate, providing Tents of the size generally sought on the market, and finally the team providing financial management training. Indicators of achievement are the realization of organization and structure, realizing a more professional equipment rental business and high economic value, which is able to increase Sekehe's income up to $80 \%$ (eighty percent) per month, and is able to know the monthly turnover through simple financial reports.

Key words: Empowerment; Sekehe Patus; Ngaben

\section{PENDAHULUAN}

Upacara-upacara keagamaan seperti ngaben sangat menjadi daya tarik tersendiri bagi wisatawan yang sedang berkunjung ke Pulau Dewata Bali. Mereka melihat ini sebagai suatu hal yang sangat berbeda dengan budaya yang ada di negara asal mereka. Bahkan sering terdapat peliputan media internasional terhadap upacara pelebon (ngaben keluarga kerajaan) yang dilaksanakan di Puri Ubud, Gianyar Bali. Ngaben merupakan suatu proses penyucian atma/roh saat meninggalkan badan kasar, dengan menggunakan sarana api sehingga bisa kembali ke Sang Hyang Pencipta yaitu Brahma. Api yang digunakan adalah api konkret untuk membakar jenazah, dan api abstrak berupa mantra pendeta untuk mem-pralina yaitu membakar kekotoran yang melekat pada atma/ roh.Dalam pelaksanaan upacara ngaben, tentunya akan memerlukan tenaga, biaya dan waktu yang tidak sedikit, hal ini kemudian secara tidak langsung melahirkan sistem pengabenan massal (bersama-sama/menyertakan orang yang banyak) dengan tujuan untuk meringankan beban tenaga dan biaya.

Dusun Silakarang sebagai salah satu dusun yang ada di Desa Singapadu Kaler, Kecamatan Sukawati, Kabupaten Gianyar, Berdasarkan pawos pada awig-awig Pekraman Silakarang yang dijadikan sumbu acuan dalam upacara pengabenan di lingkungan Pekraman Silakarang, dinyatakan bahwa: "terdapat dan berlaku 2 (dua) sistem upacara ngaben, yakni: ngaben massal (bersama-sama) dan ngaben dadakan". Secara emperik atau pengalaman di masyarakat, sistem ngaben dadakan ternyata pada umumnya relatif banyak menghabiskan biaya dan tenaga, karena dikerjakan oleh keluarga dan beberapa kerabat terdekat dari pihak yang melaksanakannya. Hal inilah yang 
secara langsung menjadi alasan sistem ngaben dadakan ini kadang ditinggalkan/dihindari. Lebih lanjut apabila mengikuti ngaben massal yang diselenggarakan pada setiap 5 (lima) tahun sekalli, dirasa sangat memberatkan dari segi waktu, karena persiapan yang dilakukan selama berbulan-bulan. Untuk itulah pada Bulan Oktober Tahun 2012 ada inisiatif dari beberapa masyarakat Dusun Silakarang untuk membentuk sekehe patus ngaben. Pembentukan ini bertujuan untuk membantu dan mencari solusi terhadap permasalahan-permasalahan yang saat ini terjadi pada pelaksanaan ngaben dadakan. Anggota sekehe patus ngaben ini sebagian besar merupakan masyarakat yang berprofesi sebagai tukang ukir, petani dan pegawai swasta.

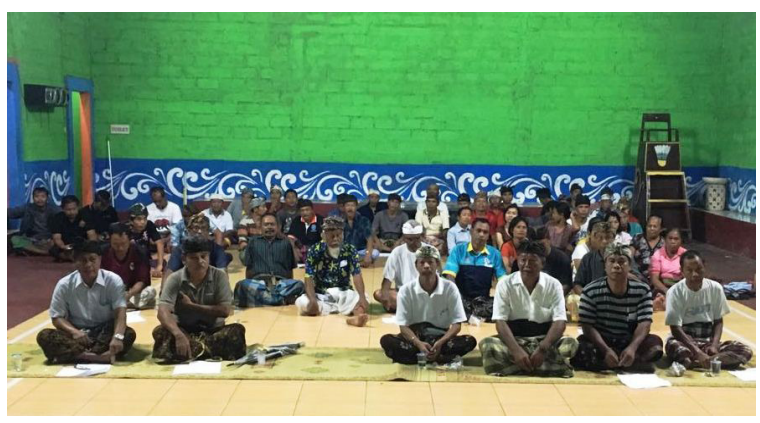

Gambar 1. Paruman Sekehe Sarwa Guna Yadnya

Berdasarkan pemaparan terhadap hasil analisa situasi existing di atas, maka diklasifikasikan permasalahan prioritas dari mitra adalah sebagai berikut:

1. Kurangnya aturan atau awig-awig yang mengatur tentang ketentuan dasar dalam tata kelola sekehe patus ngaben, selama ini hanya berbentuk sangat sederhana dan tidak lengkap.

2. Struktur organisasi yang sudah tidak sesuai dan tidak tepat, karena beberapa orang sudah meninggal dan belum dimasukkannya petugas atau orang yang ditunjuk menjadi pengelola alat-alat sekehe maupun pekerja ketika alat-alat sekehe disewa.

3. Ketersedian alat yang kurang lengkap, sehingga anggota sekehe masih harus menyewa beberapa alat pada pihak lain. Hal itu juga menyebabkan alat-alat sekehe tidak dapat disewakan secara umum seperti tempat penyewaan alat-alat upacara yang ada.

4. Kurangnya penetapan terhadap harga sewa alat-alat, sehingga penghasilan dari sewa alat upacara relatif kecil. Termasuk di dalamnya harus diatur tentang sanksi apabila alat hilang. Begitu juga terkait plang atau papan nama untuk menyewakan alat-alat, sehingga selama ini hanya diketahui oleh masyarakat sekitar dusun Silakarang saja.

5. Kurangnya tata kelola keuangan sekehe yang belum dituangkan dalam laporan keuangan sederhana. Selama ini hanya didasarkan kepercayaan anggota kepada pengurus, dan tidak dilaporkan secara periodik.

6. Kurangnya pendapatan sekehe, karena koperasi yang dimiliki oleh sekehe juga memiliki modal yang terbatas, sehingga hanya menghasilkan pendapatan yang relatif kecil, yang membuat tujuan ngaben gratis bagi anggota sekehe patus ngaben belum bisa terealisasi

\section{METODE}

Adapun prosedur kerja dari kegiatan ini dilaksanakan melalui 4 (empat) langkah kerja, yang akan dimulai dari proses sosialisasi kegiatan, pembuatan aturan atau awig-awig dan Struktur Organisasi Sekehe Patus Ngaben Sarwa Guna Yadnya Dusun Silakarang, pemberian bantuan alat-alat upacara yang belum dimiliki oleh sekehe dan mewujudkan usaha penyewaan alat-alat secara profesional, dan pembuatan dan pelatihan laporan keuangan sederhana.

Berdasarkan permasalahan prioritas yang sedang dihadapi oleh mitra, adapun beberapa solusi yang ditawarkan adalah sebagai berikut:

1. Mewujudkan keberadaan aturan atau awig-awig yang mengatur tentang ketentuan dasar dalam tata kelola sekehe patus ngaben.

2. Mewujudkan Struktur Organisasi Sarwa Guna Yadnya Tahun 2018, karena kepengurusan sudah melampaui 5 (lima) tahun dan ditambahkannya pos baru terkait pengelolaan alat-alat upacara.

3. Mewujudkan kelengkapan alat dengan memberikan bantuan alat sehingga nantinya anggota sekehe tidak menyewa lagi, bahkan sebaliknya sekehe patus Sarwa Guna Yadnya dapat menyewakan alat-alat upacara seperti usaha profesional serupa.

4. Mewujudkan penetapan harga sewa untuk alatalat upacara, begitu juga pembuatan papan nama penyewaan alat sehingga pangsa pasar lebih luas.

5. Mewujudkan laporan keuangan sekehe sederhana yang dilaporkan secara periodik, selama minimal 1 (satu) tahun sekali.

6. Mewujudkan usaha penyewaan alat-alat upacara yang dikelola secara profesional sehingga meningkatkan pendapatan sekehe/mitra

Realisasi masalah dalam kegiatan ini terdiri dari: 1. Pembuatan aturan atau awig-awig dan Struktur Organisasi Sekehe Patus Ngaben Sarwa Guna Yadnya Dusun Silakarang

Aturan atau awig-awig adalah hal yang sangat penting dalam tata kelola organisasi, karena akan dijadikan acuan dari pengurus dan anggota sekehe untuk bertindak. Di dalamnya dapat dimuat hak dan kewajiban anggota, kepengurusan, iuran wajib, penetapan banten dan pilihan tingkatan ngaben yang disepakati anggota, teknis upacara ngaben dan ketentuan lain yang penting untuk dimuat dalam ketentuan dasar sekehe patus ngaben. Nantinya awig ini akan diberlakukan dan mengikat semua anggota, dicetak dan dimiliki oleh seluruh anggota sekehe. Begitu juga dalam pembaharuan terhadap struktur organisasi yang sudah ada, mengingat harus disesuaikan dengan teknis pelaksanaan sekehe patus ngaben. 
2. Bantuan alat-alat upacara yang belum dimiliki oleh sekehe dan mewujudkan usaha penyewaan alat-alat secara profesional

Selama ini pendapatan dari sekehe patus relatif kecil dan sebagian besar bersumber dari iuran wajib sekehe setiap klaim yang dilakukan oleh anggota yang meninggal dan bersumber dari subsidi hasil/pendapat koperasi Guna Mantha yang merupakan koperasi anggota sekehe patus ngaben. Dengan dibantunya beberapa alat yang belum ada, selanjutnya anggota sekehe tidak perlu menyewa alat lagi, bahkan dapat menyewakan seperti usaha lain serupa yang sudah ada, dengan harga dan kelengkapan alat yang mampu bersaing dengan usaha lainnya.

3. Pembuatan dan pelatihan laporan keuangan sederhana Kegiatan hanya menggunakan acuan menajemen keuangan sederhana tanpa didukung alat komputer. Laporan keuangan dimaksud dapat membantu mencatat bentuk dan jumlah pengeluaran serta pemasukan yang diperoleh sekehe. Dengan adanya pencatatan transaksi keuangan ini, diharapkan sekehe/mitra dapat mengetahui jumlah pendapatan dan pengeluaran yang dilakukan selama periodik. Karena selama ini belum ada pelaporan keuangan yang dilakukan oleh pengurus secara periodik.

\section{HASIL DAN PEMBAHASAN}

\section{Sosialisasi Kegiatan}

Sosialisasi atau pengarahan kepada mitra terkait kegiatan Pengabdian kepada Masyarakat di Dusun Silakarang, Desa Singapadu Kaler, Kecamatan Sukawati, Gianyar Bali sudah dilaksanakan pada Tanggal 18 dan 25 April 2018. Pada saat itu Tim memberikan dan menyajikan materi sosialisasi secara langsung kepada mitra kegiatan di GOR Guna Mantha Silakarang. Inti dari kegiatan sosialisasi kegiatan IbM ini guna memberikan pemahaman yang mendetail dan menyeluruh terkait latar belakang, identifikasi masalah, solusi, target, sasaran dan tujuan kegiatan ini. Selait itu dalam kegiatan tersebut Tim menyampaikan jadwal kegiatan PkM ini serta mempertegas peran masing-masing pihak, baik tim dan mitra. Dari sosialisasi ini juga dicapai kesimpulan bahwa dengan kegiatan ini, diharapkan mitra mampu memperkuat kelembagaan Sekehe dan merealiasikan usaha penyewaan alat upacara yang dapat dikembangkan secara bertahap dan berkesinambungan.

2. Penguatan Kelembagaan dengan Penyusunan Awig-Awig dan Struktur Sekehe

Selama ini sekehe ini tidak memiliki aturan dalam bentuk tertulis yang dijadikan dasar pelaksanaan organisasi. Untuk itu melalui tahapan beberapa kali pertemuan bersama dengan pengurus sekehe dengan Tim Pengabdian pada Tanggal 05, 12, 19 DAN 26 Juni 2018. Hasil dari koordinasi Tim Pengabdian dengan Sekehe, adalah disepakati awig-awig sekehe yang berlaku mulai tanggal 01 Juli 2018 (akan dijabarkan pada bagian lampiran laporan ini). Selain itu telah disepakati tentang pembaharuan terhadap Struktur Organisasi Sekehe Patus Ngaben Sarwa Guna Yadnya.

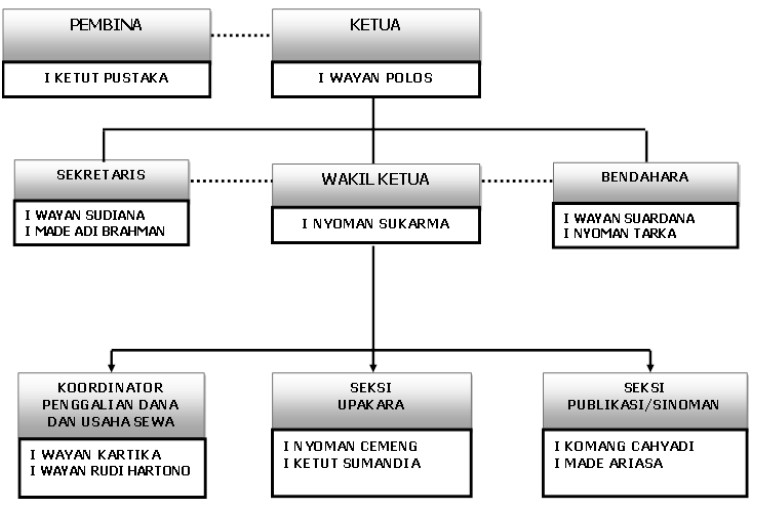

Gambar 2. Penyusunan Struktur Organisasi

3. Realisasi Usaha Sewa-Menyewa Alat-Alat Upacara dan Bantuan Alat kepada Sekehe

Tahapan kegiatan yang dilakukan selanjutnya adalah merealisasikan keberadaan usaha sewa-menyewa alat-alat upacara agama yang sebelumnya belum dioptimalkan. Pada saat proses sosialisasi dilakukan, Tim Pengabdian melihat suatu potensi yang belum dioptimalkan oleh Sekehe Patus Ngaben ini. Hal yang dimaksud adalah pengoptimalan alat-alat yang dimiliki untuk dapat disewakan dan mendapatkan hasil sewa yang dapat dipergunakan sebagai biaya ngaben yang dilakukan oleh angggota sekehe. Kurangnya pemahaman dari anggota sekehe terhadap potensi tersebut membuat tujuan dari ngaben anggota sekehe dilaksanakan dengan gratis belum terwujud. Untuk itu saat ini Tim Pengabdian sedang melakukan tahapan akhir untuk mewujudkan usaha tersebut. Langkah pertama yang telah dilakukan Tim Pengabdian dalam proses ini adalah dengan mendesain alat-alat yang belum dimiliki oleh sekehe yang dilakukan pada bulan Juni 2018, seperti 1 (satu) set Mesin yang memiliki fungsi Menggiling Daging, parut Kelapa kecil dan parut Kelapa Besar, dan 2 (dua) set Tenda. Mesin dan Tenda tersebut saat ini sudah diserahkan oleh Tim dengan disaksikan oleh Ketua Unit Pengabdian P3M Politeknik Negeri Bali. Untuk perancangan desain dan persiapan alat dan bahan dilaksanakan oleh Tim Pengabdian yang kemudian perakitannya dilakukan di Bengkel Las Dharma Putra.

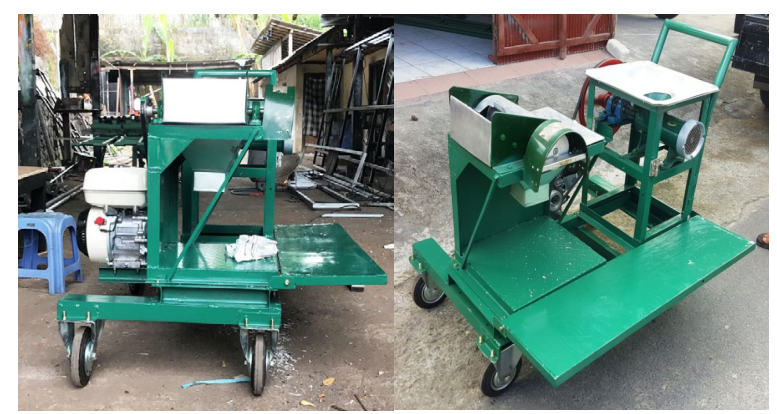

Gambar 3. Proses Pembuatan Alat 


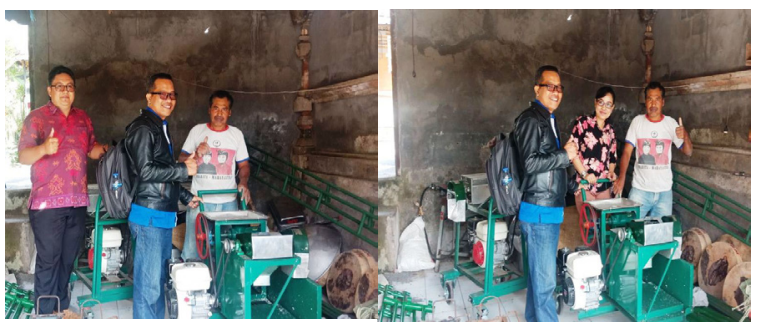

Gambar 4. Proses Penyerahan Alat

Meskipun sifatnya tidak murni dikomersilkan karena menurut hasil kesepakatan rapat umum sekehe Tanggal 20 Juli 2018, disepakati bahwa penetapan harga penyewaan alat-alat upacara adalah sebagai berikut:

Tabel 1. Penetapan Harga Sewa Sekehe Patus Ngaben Sarwa Guna Yadnya

\begin{tabular}{|c|c|c|c|c|}
\hline \multirow{2}{*}{ No. } & \multirow{2}{*}{$\begin{array}{c}\text { Keterangan/Jenis } \\
\text { Alat }\end{array}$} & \multirow{2}{*}{ Satuan } & \multicolumn{2}{|c|}{ Harga (Rp) } \\
\hline & & & Umum & Sekehe \\
\hline 1. & Perabot Mebat & $\begin{array}{l}1 \text { set/ } \\
\text { hari }\end{array}$ & 200.000 & 100.000 \\
\hline 2. & Tenda Ukuran & $\begin{array}{l}1 \mathrm{pcs} / \\
\text { hari }\end{array}$ & 100.000 & 50.000 \\
\hline 3. & $\begin{array}{l}\text { Sanggah } \\
\text { Pawiwahan }\end{array}$ & $\begin{array}{l}1 \mathrm{set} / \\
\text { hari }\end{array}$ & 150.000 & 75.000 \\
\hline 4. & Sanggah Mekarya & $\begin{array}{l}1 \mathrm{set} / \\
\text { hari }\end{array}$ & 200.000 & 100.000 \\
\hline 5. & Kursi Merah & $\begin{array}{l}1 \mathrm{pcs} / \\
\text { hari }\end{array}$ & 1.000 & 500 \\
\hline 6. & Kompor Mayat & $1 \mathrm{set}$ & 1.300 .000 & gratis \\
\hline
\end{tabular}

Anggota sekehe yang melaksanakan upacara pengabenan diberikan gratis untuk menyewa, tapi untuk kegiatan keagamaan diluar upacara ngaben akan diberikan potongan harga $50 \%$ (lima puluh persen), sedangkan untuk kalayak umum, ketentuan harga sewa yang dikenakan adalah harga sewa normal yang sudah diacuhkan penetapannya pada harga di pasaran dan sudah lebih terjangku. Hal itu dilakukan untuk menarik minat kalayak umum untuk memilih menyewa alat ke Sekehe Patus Ngaben Sarwa Guna Yadnya, sehingga dengan banyaknya transaksi yang ada, mampu meningkatkan pendapatan sekehe dalam usaha penyewaan inni.

4. Penyerahan dan Pelatihan Penyusunan Buku Pencatat Transaksi Keuangan

Penyerahan Buku Pencatat Transaksi Keuangan kepada mitra direncakan akan dilakukan Tim bersamaan dengan proses atau kegiatan Pelatihan Manajemen Keuangan Mitra. Buku ini bertujuan untuk memudahkan mitra dalam mencatat setiap transaksi keuangan yang dilakukannya sehingga nantinya dapat mengukur nilai keuntungan atau omset mitra setiap bulannya. Pada tanggal 11 Agustus 2018 sudah diberikan pemahaman kepada mitra untuk dapat menggunakan laporan keuangan sederhana untuk mengetahui omset dan penyewaan alat setiap bulannya.

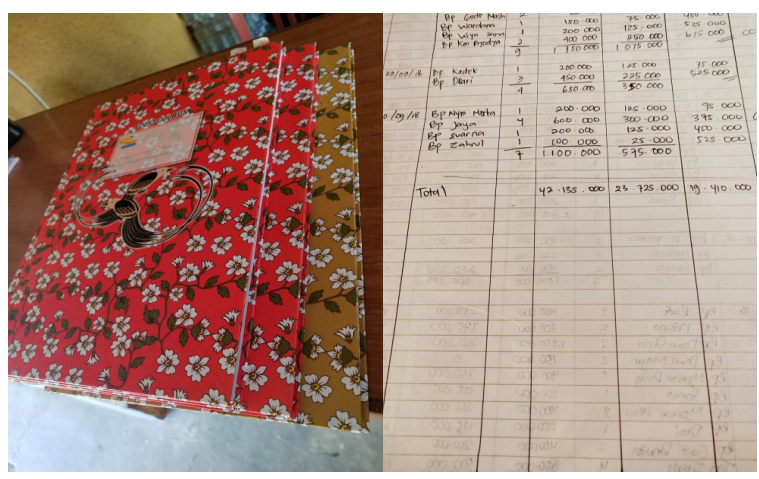

Gambar 5. Buku Pencatat Transaksi Keuangan Usaha Guna Yadnya

5. Evaluasi Kegiatan Kegiatan

Kegiatan evaluasi dilakukan untuk mengetahui hasil kegiatan yang sudah dapat terealisasikan pada mitra. Pada kegiatan evaluasi dapat diketahui bahwa semua kegiatan telah berjalan sesuai dengan yang telah direncanakan.

\section{SIMPULAN}

Berdasarkan kegiatan yang telah dilakukan sampai saat ini maka diperoleh beberapa kesimpulan, yaitu:

1. Bahwa kegiatan yang telah dilakukan sampai saat ini oleh Tim Pengabdian bersama-sama dengan mitra antara lain: kegiatan sosialisasi; penguatan kelembagaan dengan penyusunan awig-awig sekehe dan struktur organisasi sekehe; pemberian bantuan berupa alat-alat untuk realisasi usaha penyewaan alatalat upacara yang dimiliki oleh Sekehe Patus Ngaben Sarwa Guna Yadnya; Finalisasi Realisasi Usaha SewaMenyewaAlat-Alat Upacara; Penyerahan dan Pelatihan Penyusunan Buku Pencatat Transaksi Keuangan; dan Penyelesaian Pembuatan Laporan Akhir Kegiatan.

2. Bahwa bantuan alat-alat untuk realisasi sewa sudah melengkapi kekurangan alat-alat yang selama ini terjadi, sehingga kedepannya dapat direalisasikan usaha penyewaan miliki sekehe.

3. Bahwa mitra menyatakan sangat tertarik (antusias) dan terbantu karena telah mendapatkan bantuan berupa penguatan kelembagaan dan realisasi penyewaan alat.

\section{UCAPAN TERIMAKASIH}

Terima kasih kepada Direktorat Riset dan Pengabdian Masyarakat, Direktorat Jenderal Penguatan Riset dan Pengembangan Kementerian Riset Teknologi dan Pendidikan Tinggi Republik Indonesia dan Politeknik Negeri Bali yang telah memberikan kesempatan kepada kami untuk mendapatkan bantuan pendanaan kegiatan Pengabdian kepada Masyarakat ini.

\section{DAFTAR PUSTAKA}

Kontant, Schafer J. B., J. A., \& Riedl, J. 2001. E-Commerce Recommendation Applications. Data Mining and Knowledge Discovery 
Silondae, Arus Akbar \& B. Ilyas, Wirawan. 2011 Pokok-Pokok Hukum Bisnis. Salemba Empat. Jakarta

Strands Business Services. 2010. Best Practices for Product Recommendations on eCommerce Websites
Sutrisno. 2010. Akuntansi Proses Penyusunan Laporan Keuangan. Ekonisia. Daerah Istimewa Yogyakarta 